\title{
Annotated checklist of Chinese mainland Dasyvalgus, with description of nine new species
}

\author{
(Coleoptera Scarabaeidae Cetoniinae)
}

\begin{abstract}
Riassunto: Checklist commentata delle specie cinesi del genere Dasyvalgus, con descrizione di nove nuove specie (Coleoptera Scarabaeidae Cetoniinae).

Il genere Dasyvalgus Kolbe, 1904, è, tra i Valgina, quello che include il maggior numero di specie. In Cina, prima di questo studio, era rappresentato da sole cinque specie. Nove nuove specie (Dasyvalgus becvariensis Ricchiardi n.sp., Dasyvalgus benesi Ricchiardi n.sp., Dasyvalgus ligthbrowni Ricchiardi n.sp., Dasyvalgus minutus Ricchiardi n.sp., Dasyvalgus motuoensis Ricchiardi n.sp., Dasyvalgus paratomentatus Ricchiardi n.sp., Dasyvalgus rufipes Ricchiardi n.sp., Dasyvalgus tomentatus Ricchiardi n.sp., Dasyvalgus varius Ricchiardi n.sp.) sono ora descritte e documentate. Includendo queste nuove specie, nuove sinonimie e segnalazioni il genere Dasyvalgus è ora rappresentato in Cina (a esclusione di Taiwan) da diciassette specie. Inoltre le femmine di cinque di esse sono descritte o illustrate ed è fornita una chiave dicotomica utile alla determinazione dei maschi.
\end{abstract}

\begin{abstract}
The genus Dasyvalgus, is the largest of Valgina and in mainland China was previously represented by five species only. Nine new species (D. becvariensis, D. benesi, D. ligthbrowni, D. minutus, D. motuoensis, D. paratomentatus, $D$. rufipes, $D$. tomentatus, $D$. varius) are here described and illustrated. Including the new species, new synonymies and new records, presented here, the mainland Chinese Dasyvalgus now consists of seventeen species. Moreover, the females of five species are described or illustrated, and a key for the identification of the males is provided.
\end{abstract}

Key words: Coleoptera, Valgina, Dasyvalgus, new species, new synonyms.

\section{INTRODUCTION}

Until recently the known Chinese mainland species of Dasyvalgus Kolbe, 1904 numbered only five, most of them inhabiting the provinces of the Southeast: these were D. ichangicus (Moser, 1915), D. laligantii (Fairmaire, 1888), D. sebastiani Endrödi, 1952 and D. sommershofi Endrödi, 1952. A fifth species, Dasyvalgus sellatus (Kraatz, 1883) was added by Krajcik (2011) on the basis of a specimen from Hong Kong identified by Kraatz; however, Kraatz had misidentified the specimen and D. sellatus in reality is actually not part of the Chinese fauna (see discussion under Taxonomy section below). Recently, another species, D. rugosus Ricchiardi 2013, was added to the list of those occurring in China.

The study of many specimens of Dasyvalgus I have accumulated over the years, mainly caught in the 1990s by many eastern European entomologists, of more recent by local collectors, and with the study of IZAS collection (Bejing) made by Sha Li, has led to the identification of nine new species. With the decision to place D. sebastiani Endrödi, 1952 as junior synonym to $D$. inouei Sawada, 1939 (new jun. syn.) and three new records for China - Dasyvalgus carbonarius (Arrow, 1910), Dasyvalgus montivagus, (Moser, 1915) and Dasyvalgus penicillatus (Blanchard, 1850), the total number of Chinese Dasyvalgus rises to seventeen.

Given the great variety of biotopes and the vastness of the country, future research will undoubtedly lead to the discovery of new species and to a better knowledge of their ecology and distribution. The current paper will, hopefully, provide a good foundation for future studies.

"Enrico Ricchiardi, Corso A. Tassoni 79/4, 10143 Torino, Italy. E-mail: alericor@fastwebnet.it

${ }^{* *}$ Sha Li, Key Laboratory of Zoological Systematics and Evolution, Institute of Zoology, Chinese Academy of Sciences, Box 92, Beichen West Road, Chaoyang District, Beijing, 100101, China; University of Chinese Academy of Sciences, Yuquan Road, Shijingshan, Beijing, 100039, China. E-mail: lisha1988cc@163.com 
Dasyvalgus is the largest genus within Valgina, and currently comprise about 136 species (including those described or synonymised here), but many others are awaiting description and the total number may rise over 150 .

Dasyvalgus is a genus of Valgina belongings to the Oriental Region fauna. The distribution of the species is bounded on the north by a line that extends from the southern Himalayan sub-region to the centre of Japan, excluding Korea. The southern boundary is formed by a line that extends from Sri Lanka to Lombok, Sulawesi and the Moluccas. Some species is present in the Chinese Transition Zone (Zona di Transizione Cinese, sensu Palestrini et al., 1985) where the Palaeartic and Oriental fauna are simultaneously present (Ling et al., 2008). One species, Dasyvalgus tuberculatus (Lewis, 1887) inhabits the south-central region of the Japan mainland, part of the Palaeartic region. Oddly, one species, Dasyvalgus mexicanus (Cazier, 1937), lives in Mexico and was recently included in the genus (Jameson et al., 2005). Actually, the morphological analysis of this species support its inclusion in Dasyvalgus. However, it is possible that the finding of the female, currently unknown, or a genetic study comparing this species with Chinese's counterpart could lead to a different diagnosis.

Females of Dasyvalgus are much less often collected than males, but in the case of the Chinese species we already know females for six of them $(D$. becvariensis, $D$. benesi, $D$. inouei, $D$. carbonarius, $D$. penicillatus and D. sommershofi), which provides a good insight into their general morphology. They differ from their males counterparts in their size (being wider and longer), in the shape of pronotum (generally more squared anteriorly), sometimes also for the shape of posterior pronotal margin (see D. penicillatus), in the shape of propygidium and pygidium, in their enlarged protibiae, and in their shorter suctorial brush.

Five species of Dasyvalgus from the mountains of south western China are described below, (D. benesi, D. paratomentatus, D. ligthbrowni, D. tomentatus and $D$. varius). In each of these, males are characterized by having four rounded white cretaceous maculae on the pygidium (Fig. 1), a character shared with $D$. ovicollis Arrow, 1910, from Myanmar. One of the Chinese species (D. ligthbrowni) actually resembles very similar to $D$. ovicollis, but the parameres are distinctive Fig. 2j). Moreover, a male of one Vietnamese species, Dasyvalgus montivagus Moser, 1915, sharing the same character, was found on Dayaoshan Mountains (Guangxi, new record for China). See Fig. 3 for distribution of these species.

Although the pattern formed by elytral scales is very similar (Fig. 2), these seven species can be separated by the shape of the parameres (Fig. 2) and other morphological characters highlighted in the descriptions and in the dichotomous key. Contrary to what normally happens in Dasyvalgus, these species show a great variability in the shape of their parameters.

Currently, we do not separate them into a defined species group for the following reasons: the only known female ( $D$. benesi), herein described, does not have white cretaceous areas or markings on the pygidium; the other morphological characters shared by the six species (for example, the shape and size of the of protibial teeth) are not unique; while sharing pattern of scales on the elytra, this is very similar to that observed in other Dasyvalgus species from China ( $D$. becvariensis, D. ichangicus; Fig. 4a,b,f) and from elsewhere - for instance D. ovicollis and D. tuberculatus (Lewis, 1887), the latter species from Japan. There is no doubt, however, that these five species are closely related to each other and to D. montivagus and D. ovicollis.

Three Chinese species, D. minutus, D. motuoensis, and D. penicillatus (Blanchard, 1850) occur in the valleys of south Xizang ending in Arunachal

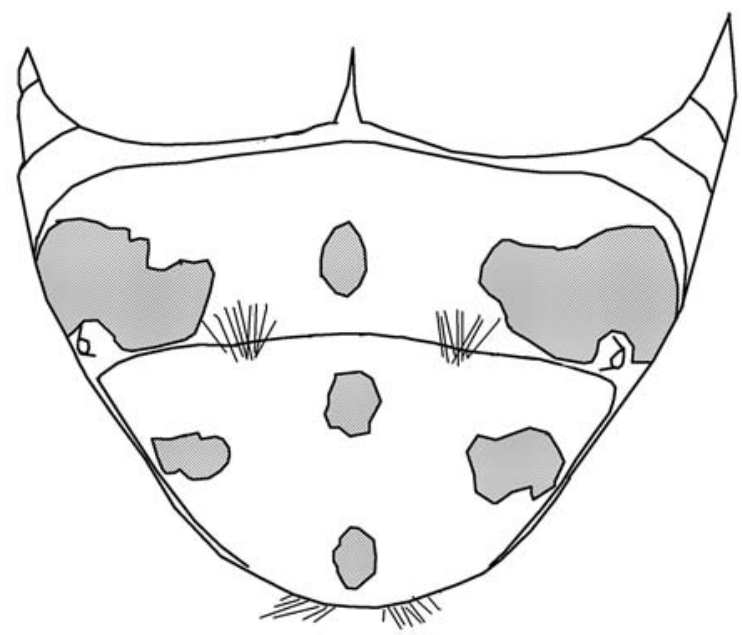

Fig. 1. Propygidium and pygidium of a PT $\widehat{\delta}$ ERC of $D$. ligthbrowni. 

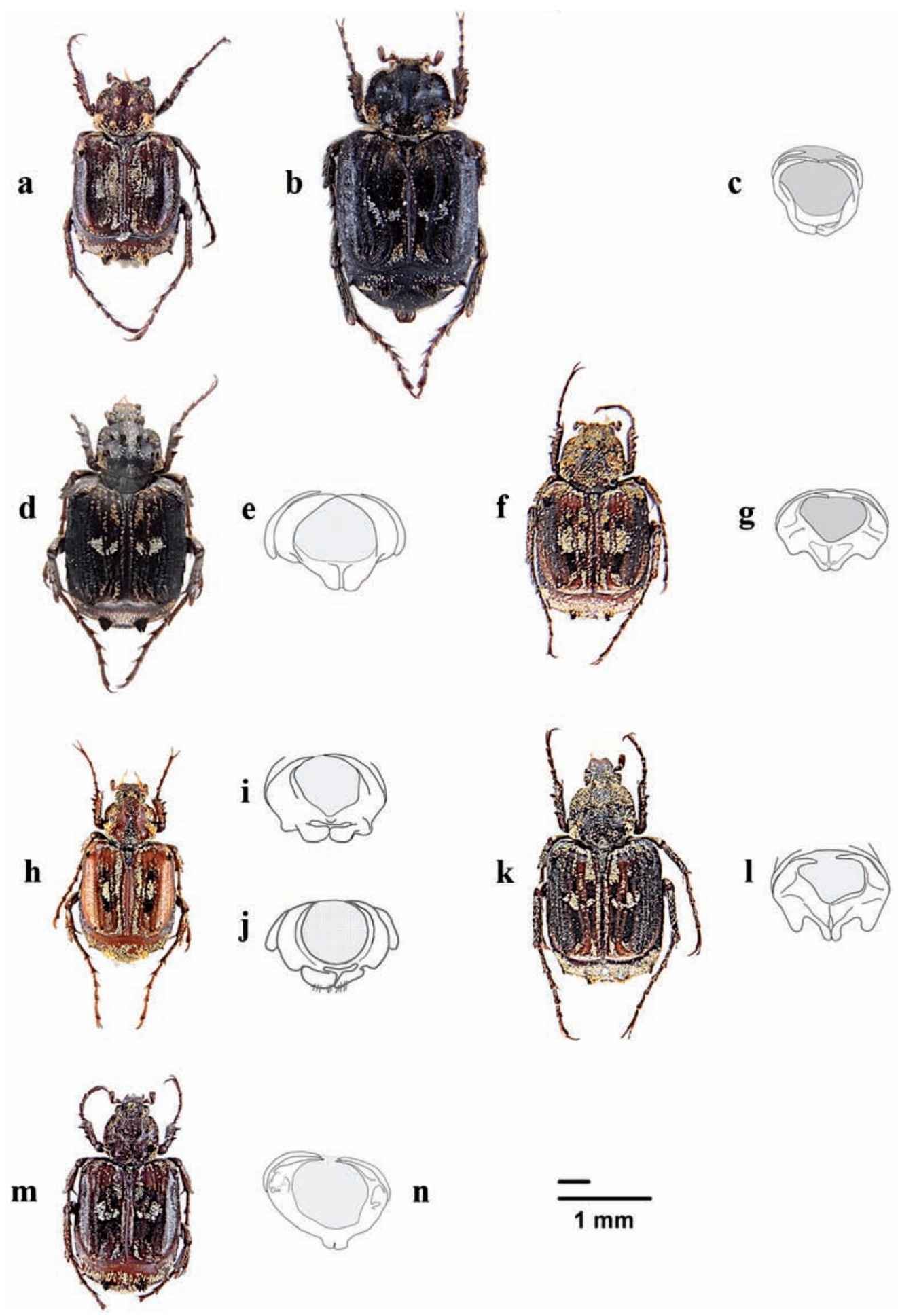

$\mathbf{n}$

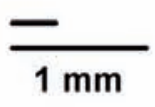

Fig. 2. Habitus and parameres of: a-c - D. benesi (a, PT male, b PT female) both ERC; d,e - D. montivagus, male ERC; f,g D. paratomentatus HT male IZAS; h, $\mathrm{i}-D$. ligthbrowni PT male ERC; $\mathrm{k}, 1-D$. tomentatus HT male IZAS; $\mathrm{m}, \mathrm{n}-$ D. varius PT male ERC; j, parameres of HT male of D. ovicollis NHM. 
Pradesh, which are associated with north eastern India, southern Himalaya and northern Myanmar.

Of the other Chinese species, it is remarkable that $D$. sebastiani is found to be junior a synonym (syn. nov.) of $D$. inouei, a Taiwan species. To this point in time, six Dasyvalgus species have been described from Taiwan (Dasyvalgus formosanus Moser, 1915; D. inouei Sawada, 1939; Dasyvalgus makiharai Miyake, 1985, Dasyvalgus sauteri Ricchiardi, 1998; Dasyvalgus taiwanus Miyake, 1991 and Dasyvalgus wadai Miyake, 1985), one of which also occurs on mainland China. The five endemic Taiwan species of Dasyvalgus certainly show the relatively long faunistic isolation of Taiwan from the mainland.

As could be expected, four species are shared with Indochina (D. carbonarius, D. laligantii, D. montivagus with North Vietnam; D. rufipes, with Laos) and these could only increase in the future.

The new species and new synonymies are settled by E. Ricchiardi; unless elsewhere specified, all photograph and drawings were made by E. Ricchiardi.
Key to abbreviations of some taxonomical characters and remarks (Fig. 5):

aut anteapical umbone scale tuft. Rarely absent

c carina. Can be obsolete or more or less sharp and more or less long; the two carinae maybe parallel or arched outwardly

cct central carina scale tuft. Sometimes not present csc central small carina. Sometimes not present

cpt carina posterior tuft. The carina not always reach this scale tuft. Sometimes the scale tuft not present

lsc lateral small carina. More or less long. Sometimes not present

pat posterior angle scale tuft. Sometimes not present pt propygidium scale tuft. Always present, often prominent

ut humeral umbone scale tuft. Rarely absent.

The following nomenclatural acts are presented herein:

- description of nine new Dasyvalgus (new species)

- designation of Dasyvalgus sebastiani Endrödi,

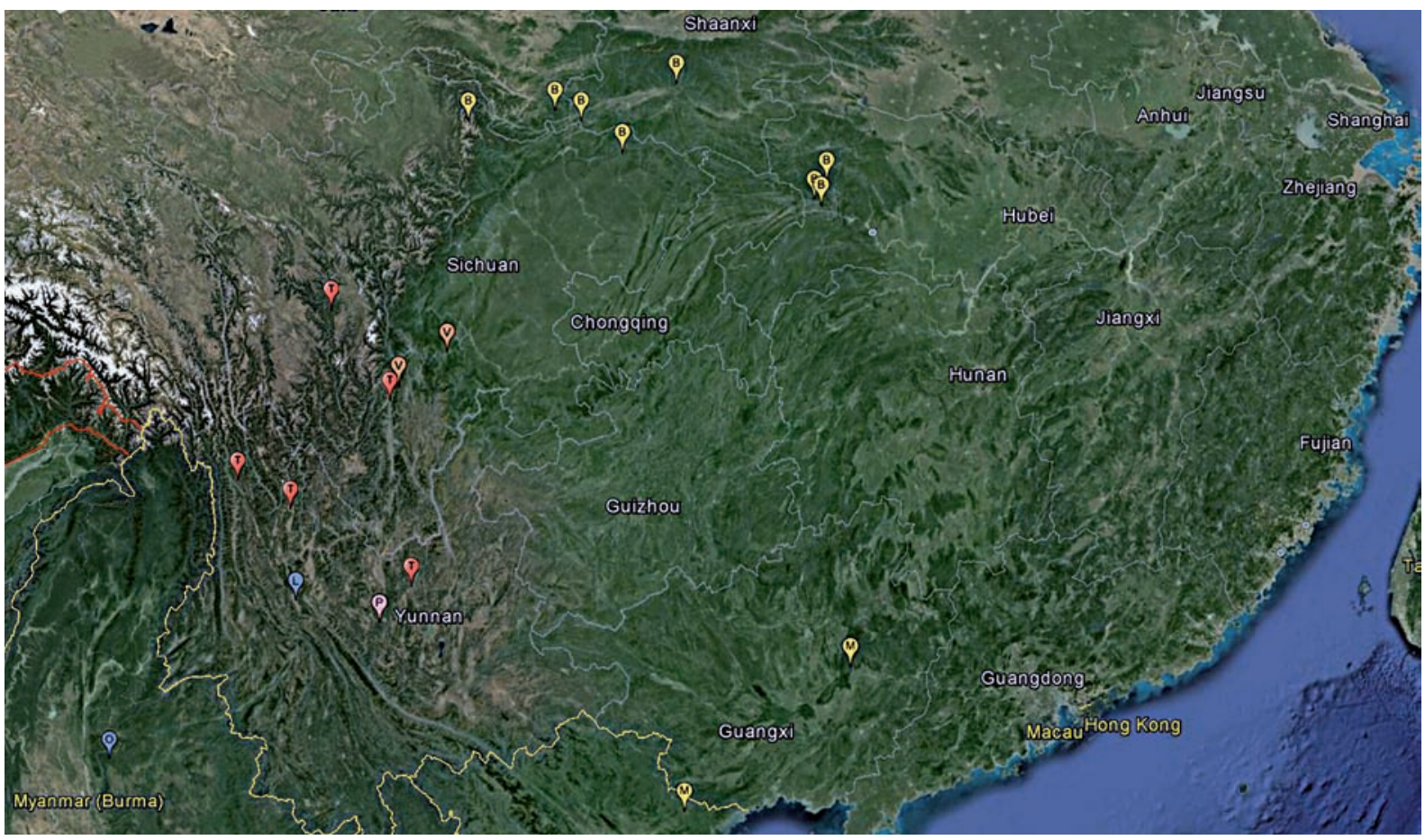

Fig. 3. Distribution of the species with four cretaceous markings on pygidium. B, D. benesi; L, D. lightbrowni; M, D. montivagus; O, D. ovicollis; P, D. paratomentatus; T, D. tomentatus; V, D. varius. 
1952 as junior synonym of Dasyvalgus inouei Sawada, 1939 (new synonym)

- designation of type series of Dasyvalgus laligantii (Fairmaire, 1888)

- designation of type series of Dasyvalgus sellatus (Kraatz, 1883)
- first description of females of $D$. becvariensis, $D$. benesi, and D. sommershofi

- new records for China of D. Carbonarius, D. montivagus and D. penicillatus

- designation of type series of D. montivagus Moser, 1915.
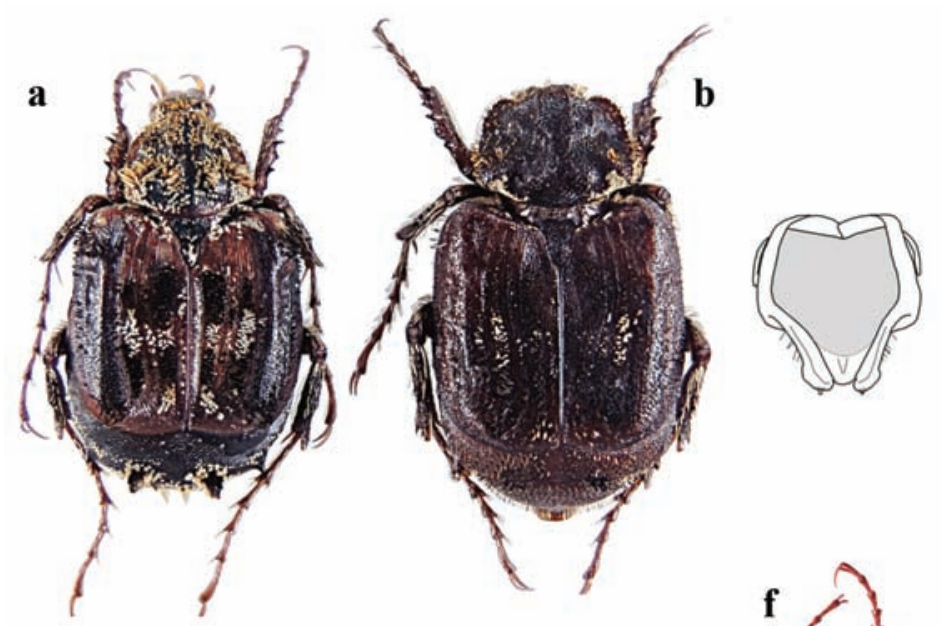

c
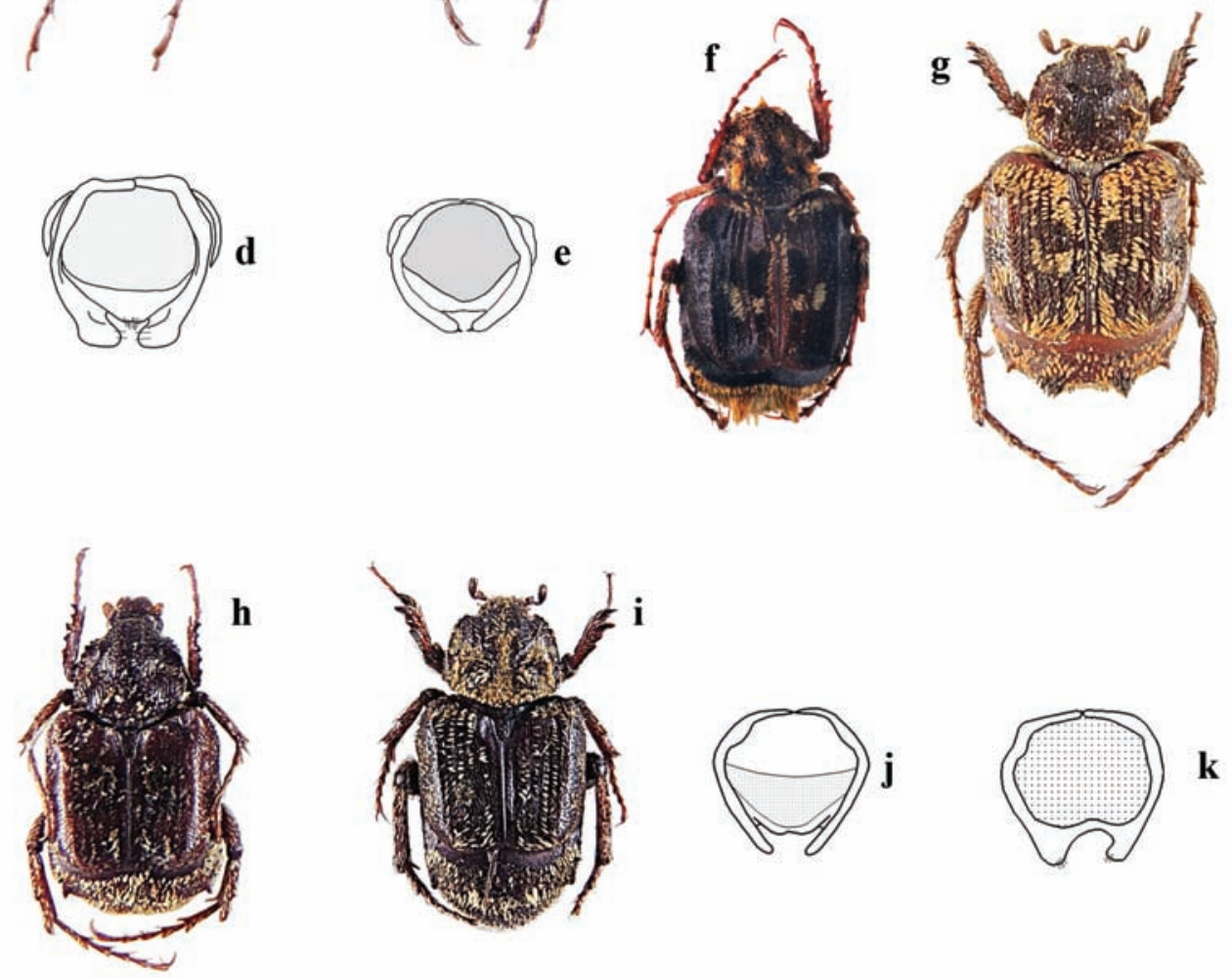

Fig. 4. Habitus and parameres of: a-c $-D$. becvariensis (a, PT male, b, PT female, both ERC); $\mathrm{d}, \mathrm{f}-D$. ichangicus (HT male MNHUB; photo Sha Li, Bejing); e, g-D. laligantii; h-j, D. sommershofi (h, male, i, female); k, parameres of D. sellatus. 


\section{MATERIALS AND METHODS}

Most of type specimens of species discussed in this paper were examined and are detailed under the taxonomy section of each species The total length of a specimen was measured from the anterior margin of the pronotum (because, as already pointed out by Arrow, 1910, pag. 222: the head of Dasyvalgus, and most Valgina, is capable of being folded closely beneath the sternum, being then concealed from above by the prominent front part of the pronotum) to the apex of pygidium (excluding the protrusion at apex of pygidium in some females); specimen width is the maximum width of the elytron. Measurements were taken using the millimeter grid of the binocular microscope. Photographs of holotypes were taken with a Nikon Coolpix P7700, attached to one of the eyepieces of a Wild dissecting microscope or with the same camera but without the microscope. Photographs were processed with photo stacking software (Zerene

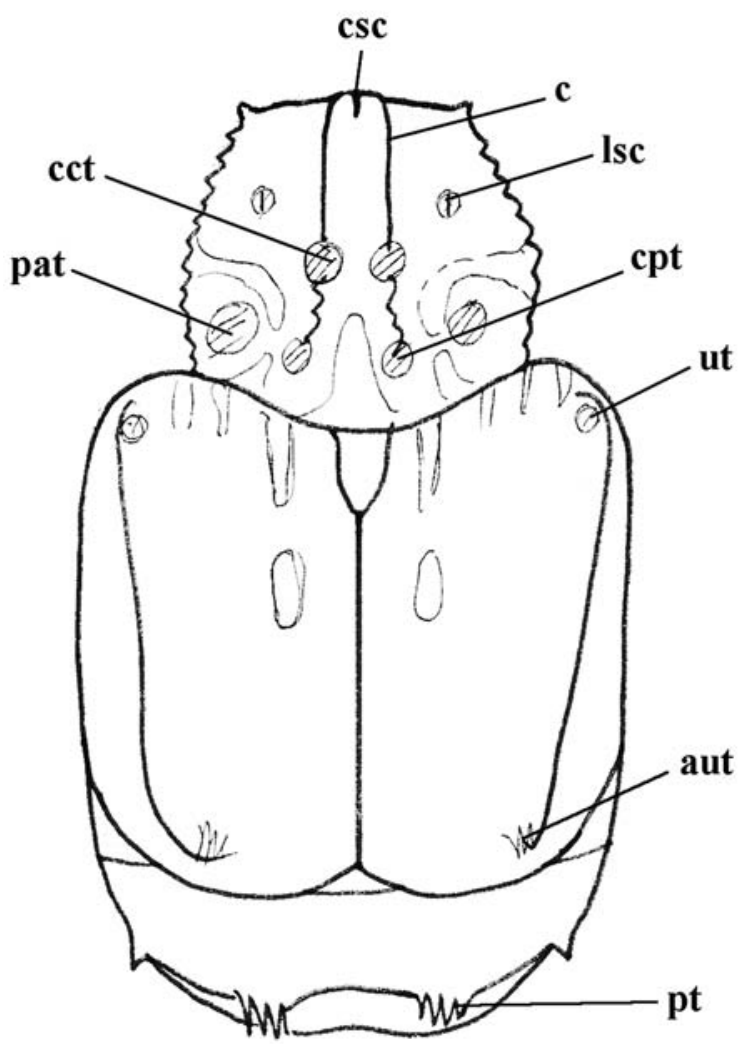

Fig. 5. Some descriptive morphological terms of Dasyvalgus.
Stacker - Version 1.04 Build T201411272115, http://www.zerenesystems.com). Finally, backgrounds were removed from photos using GIMP 2.8.14, in order to increase clarity.

\section{ABBREVIATIONS USED}

Scientific collections:

ERC Enrico Ricchiardi Collection, Turin, Italy

AMNH American Museum of Natural History, New York, USA

HNHM Hungarian Natural History Museum, Budapest, Hungary

IZAS Institute of Zoology, Chinese Academy of Science, Bejing, China

MHNG Musée d'Histoire Naturelle, Geneve, Swizerland

MNHN Museum National d'Histoire Naturelle, Paris, France

MNHUB Museum für Naturkunde, Berlin, Germany

MZF Museo Zoologico, La Specola, Florence, Italy

NHM The Natural History Museum, London, UK

NHMB Natural History Museum, Basel, Swizerland

NMER Naturkunde Museum, Erfurt, Germany

SDEI Deutsche Entomologische Institut Munchberg, Germany

SNMS Stuttgart Staatliche Museum für Naturkunde, Stuttgart, Germany

USNM United States National Museum, Smithsonian Institute, Washington DC, USA

ZMHA Zoological Museum, Halle, Germany

ZFMK Zoologisches Forschunginstitut und $\mathrm{Mu}$ seum Alexander König, Bonn, Germany

ZMUC Zoological Museum University of Copenhagen, Denmark

Types:

$\begin{array}{ll}\text { CT } & \text { Cotypes } \\ \text { LT } & \text { Lectotype } \\ \text { HT } & \text { Holotype } \\ \text { NT } & \text { Neotypes } \\ \text { PLT } & \text { Paralectotype } \\ \text { PT } & \text { Paratype }\end{array}$

SPECIES LIST

becvariensis Ricchiardi n. sp. Yunnan, Sichuan benesi Ricchiardi n. sp. Sichuan, Shaanxi, Hubei, Gansu carbonarius Arrow, 1910 Nepal, Assam, 


\begin{tabular}{|c|c|c|}
\hline & & $\begin{array}{l}\text { Myanmar, } \\
\text { Thailand, Laos, } \\
\text { Vietnam, Hainan }\end{array}$ \\
\hline ichangicus & Moser, 1915 & Hubei \\
\hline inouei & Sawada, 1939 & $\begin{array}{l}\text { Taiwan, Fujian, } \\
\text { Guangxi }\end{array}$ \\
\hline$=$ sebastiani & Endrödi, 1952 & Fujian \\
\hline laligantii & (Fairmaire, 1888) & $\begin{array}{l}\text { Vietnam, Fujian, } \\
\text { Gaungxi, Hong } \\
\text { Kong }\end{array}$ \\
\hline ligthbrowni & Ricchiardi n.sp. & Yunnan \\
\hline minutus & Ricchiardi n. sp. & Xizang \\
\hline montivagus & Moser, 1915 & Vietnam, Guangxi \\
\hline motuoensis & Ricchiardi n. sp. & Xizang \\
\hline aratomentatus & Ricchiardi n. sp. & Yunnan \\
\hline penicillatus & (Blanchard, 1850) & $\begin{array}{l}\text { Nepal, Bhutan, } \\
\text { India, Xizang }\end{array}$ \\
\hline rufipes & & $\begin{array}{l}\text { Ricchiardi n. sp. } \\
\text { Laos, Guangxi, } \\
\text { Hainan }\end{array}$ \\
\hline rugosus & Ricchiardi, 2013 & Yunnan \\
\hline sommershofi & Endrödi, 1952 & Fujian \\
\hline tomentatus & Ricchiardi n. sp. & Yunnan, Sichuan \\
\hline varius & Ricchiardi n. sp. & Sichuan \\
\hline
\end{tabular}

\section{TAXONOMY}

Dasyvalgus becvariensis Ricchiardi n. sp. (Fig. 4a-c). TYPE SERIES. HT $\lesssim$ IZAS, Yunnan, Gongshan County, Danzhu to city $\left(27^{\circ} 41^{\prime} 24^{\prime \prime} \mathrm{N}, 9^{\circ} 39^{\prime} 00^{\prime \prime} \mathrm{E}\right), 2000 \mathrm{~m}$, Sino-America Expedition, 5 Jul 2000, legit H.B. Liang; 1 PT $\lesssim$ IZAS, Yunnan, Deqin, Meili Snow Mountains (28²7'36”N, 98 50'46”E), 3700-4000 m, 29 Jul 1982, leg. Wang Shuyong; 1 PT $\precsim$ IZAS, Yunnan, Deqin, Meili Snow Mountains (28 $27^{\circ} 36^{\prime \prime N}$, 9850'46”E), 3450 m, 29 Jul 1982, leg. Zhang Xuezhong; 1 PT $\curvearrowright$ IZAS, Yunnan, Deqin, Meili Snow Mountains (28²7'36”N, 98 50'46”E), 3200-3500 m, 23 Jul 1982, leg. Wang Shuyong; 1 PT $\curvearrowright$ 1 PT $q$ ERC, China, Yunnan, Heishu, $35 \mathrm{Km}$ North of Lijiang, 18 Jun/4 Aug 1993, S. Bečvář legit; 1 PT đ IZAS, Sichuan, Wenchuan, Wolong ( $31^{\circ} 02^{\prime} 45^{\prime \prime} \mathrm{N}, 103^{\circ} 12^{\prime}$ 17’E), 25 Jul 1983, leg. Wang Shuyong.

Holotype DESCRIPTION. Length $6.8 \mathrm{~mm}$, width $4.7 \mathrm{~mm}$.

Head: brown, slightly shiny, covered with large shallow punctures and with testaceous, inclined, bristle like scales that do not form tufts. Clypeus brown, almost glabrous, anteriorly sinuate, covered with same punctuation; suctorial brush longer than clypeal length.
Pronotum: dark brown, laterally and posteriorly brown, covered with recumbent scales which are either testaceous or white; trapezoidal, medially convexly arched; anterior angles acute; posterior angles right angled, with apex pointed; sides crenate; carinae sharp and curved outwardly, ending at centre of disk; without central small carina; lateral small carinae obsolete; small black scales tufts at end of carinae and with mixed black and testaceous scales on lateral small carinae; posterior margin with four prominent testaceous scale tufts, the inner two a bit smaller.

Scutellum: long, approximately triangular, apically obtuse, covered with bristle like, inclined, testaceous and black scales.

Elytra: slightly shiny, mostly glabrous, brown or black in some places, with lateral margins a slightly widened medially; in some places covered with black or testaceous inclined small scales that form a definite pattern (Fig. 4a,b). Humeral umbones well developed, rounded, each covered with a prominent black scale tuft. Anteapical umbones similarly prominent, covered with identical, less developed, black scale tufts.

Propygidium: brown, opaque, mostly glabrous, covered with round, thick, punctuation; with scattered, recumbent, testaceous scales; posterior margin curved inward at the middle, with two prominent tufts made of erect, long, black and testaceous scales; cones sharp.

Pygidium: brown, opaque; covered with dense round punctuation and very scattered, recumbent, testaceous scales; ventral half constricted to apex, laterally narrowed; apex forming a rounded projection on which a double pointed testaceous scale tuft occurs; apex of pygidium curving outward in lateral view.

Protibia: brown, with five external teeth: first three long and pointed, fifth smaller and pointed, fourth large, short and rounded.

Meso and metatibiae: brown, black in some places, centrally enlarged, with noticeable central tooth, and some scattered, long, erect, testaceous scales; first metarsomere about twice as long as second. Abdomen: dark brown, nearly glabrous, with some small, testaceous, recumbent scales on the sternites; anal sternites brown, glabrous, covered with round, shallow, large punctuation.

PARATYPe Female DesCriPTION. Length $7.0 \mathrm{~mm}$; width $4.1 \mathrm{~mm}$. Body brown.

Head: slightly shiny, covered with large round punctures and with scattered, erect, bristle like testaceous scales that do not form scale tufts on frons. Clypeus 
anteriorly sinuate, suctorial brush much shorter than in male.

Pronotum: brown, opaque, trapezoidal, strongly crenate at sides, anterior angles obtuse, posterior angles pointed; posterior margin curved towards scutellum, centrally depressed; carinae outwardly slightly arched, sharp up to centre of disk, rounded posteriorly, ending at 3/4 length of pronotum; central small carina not present; lateral carinae long, sharp; with two testaceous scale tufts present, close to posterior angles; remainder of surface glabrous, with scattered testaceous scales along lateral margins; laterally, the posterior margin with a white, cretaceous area.

Scutellum: black, long, triangular, apically rounded, longitudinally shagreened.

Elytra: brown, in some places black, slightly shiny, mostly glabrous, with shallow juxtascutellar depression; humeral and anteapical umbones slightly elevated, without scale tufts.

Propygidium: brown, slightly shiny, glabrous, covered with dense round punctuation; posterior margin curved inward at the middle, with two small tufts of erect, black scales; cones long and blunt.

Pygidium: brown, slightly shiny, almost glabrous, covered with dense round punctuation; apical half constricted to the apex, the apex forming a rounded projection, wider than that in male; in lateral view, apex of pygidium projecting posteriorly.

Protibiae: brown, with five external teeth: first long and pointed, second and fifth small and blunt, third small and pointed, fourth enlarged and blunt.

Meso and metatibiae: dark brown, centrally enlarged, with several noticeable sharp teeth, and some scattered, long, erect, testaceous scales; metatibial apex enlarged and slightly crenate, dorsal end long and pointed; first metarsomere apically enlarged, about twice as long as second.

Abdomen: brown, nearly glabrous, with some testaceous small, bristle like, erect, testaceous scales on the last two visible sternites; anal sternites brown, glabrous, with a row of small, erect, bristle like, testaceous scales on lateral margins.

DisTRIBUTION. This species looks to be distributed on high mountains between north-west Yunnan to central Sichuan.

TYPE SERIES VARIABILITY. The body of one PT $\widehat{\partial}$ (ERC) is black instead of brown; its pygidium shows two small, barely noticeable cretaceous markings close to centre of lateral margins.
REMARKs. Females differ from males in their squared pronotum, with lateral margins crenate; for lack of scale tufts on pronotum; for the wider rounded projection at apex of pygidium.

DERIVATIO NOMINIS. The species is dedicated to Stanislav Bečvár who collected the specimens during one of his entomological trips

DiAGNOSIS. This species has the same scale pattern on the elytra as many other Chinese Valgina, but can be separated from them for the pygidium which is mostly glabrous and without any cretaceous areas or markings; moreover, the apex of the pygidium exhibits a prominent rounded projection. The shape of the parameres is also very distinctive (Fig. 4c) in this species.

Dasyvalgus benesi Ricchiardi n. sp. (Fig. 2a-c).

TYPE SERIES. HT $\lesssim$ IZAS, China, Shaanxi, Foping, Changjiabaxiang $\left(33^{\circ} 35^{\prime} 22^{\prime \prime} \mathrm{N}, 108^{\circ} 00^{\prime} 35^{\prime \prime} \mathrm{E}\right), 20$ May 2007, Zhang Lijie legit. Paratypes: 1 PT $\widehat{\partial}$ ERC, Shaanxi, Lueang env. $15 \mathrm{Km}$ NW $\left(33^{\circ} 07^{\prime} \mathrm{N}\right.$, $\left.106^{\circ} 07^{\prime} \mathrm{E}\right), 18 / 21 \mathrm{Jul} 2001$, E. Kucera legit; 3 PT $ठ$ ERC, China, Sichuan, Juzhaigou Songpan Co (County), 3000 m, 4/7 Jul 1994, Beneš legit; 1 PT ㅇ SNMS, 1 PT 9 ERC, Sichuan, Juzhaigou, 2000m, 16 Jun 1992, M. Bok legit; 1 PT ô ERC, Sichuan, Shangliang, 24/26 May 2005, E. Kucera legit; 1 PT $ठ$ ERC, Sichuan, Juizaigou, 13 Jun 2009, E. Kucera legit; 1PT ô 1 PT + $\mathrm{ERC}$, same data but 13/19 Jun 2009; 1 PT đ̊ ERC, Sichuan, 30 Km W Nanping, Juzhaigou, 2100 m, 11/16 Jun 1992, J. Turna legit; 4 PT § IZAS, Gansu, Kangxian, 17 May 1981, Meng Tienan legit; 6 PT $\curvearrowright$ IZAS, Hubei, Shennongjia, Songbai ( $\left.31^{\circ} 28^{\prime} 43^{\prime \prime} N, 110^{\circ} 24^{\prime} 44^{\prime \prime} \mathrm{E}\right), 900 \mathrm{~m}, 8$ Jun 1981, Hai Yinheng legit; 1 PT $\widehat{\partial}$ IZAS, Hubei, Shennongjia, Muyuping ( $31^{\circ} 28^{\prime} 17^{\prime}{ }^{\prime} \mathrm{N}, 110^{\circ} 24^{\prime} 15^{\prime}$ 'E), 1250 m, 4 Jul 1981, Hai Yinheng legit; 1 PT ठ̂ IZAS, Hubei, Xinshan, Longmen River $\left(31^{\circ} 21^{\prime} 33^{\prime} \mathrm{N}\right.$, $110^{\circ} 31^{\prime} 03$ 'E), $1400 \mathrm{~m}$, Sun Baowen legit.

HOLOTYPE DESCRIPTION. Length $5.4 \mathrm{~mm}$, width $3.4 \mathrm{~mm}$.

Head: black, slightly shiny, covered with shallow, large punctures and very scattered, erect, bristle like, testaceous scales not forming tufts; frons with a rounded prominence at centre. Clypeus brown, anteriorly sinuate, covered with same punctuation, almost glabrous; suctorial brush longer that clypeus length. Pronotum: brown, ovate, medially convexly arcuate; front angles rounded; posterior angles strongly rounded; lateral sides crenate; carinae sharp up to centre of disk, 
obtuse afterward, curved outwardly; central small carina not present; lateral small carinae obsolete; covered with very scattered, testaceous, recumbent scales; small black scale tufts at end of carinae; along posterior margin four testaceous scale tufts, the outer two prominent, the inner two barely noticeable.

Scutellum: long, approximately triangular, apically rounded, covered with recumbent, testaceous scales.

Elytra: slightly shiny, mostly glabrous, in some places brown or black, with lateral margins a bit widened outwardly; in some places covered with black, white or testaceous inclined small scales forming a definite pattern (Fig. 2a); humeral umbones rounded and prominent, with black scale tufts; anteapical umbones rounded and prominent, with black/testaceous scale tufts.

Propygidium: brown, slightly shiny, glabrous in some places, with dense, recumbent, testaceous scales elsewhere; posterior margin curved inward at the middle, with two black/testaceous scale tufts; cones sharp; rounded, white cretaceous areas at centre and laterally, close to the cones.

Pygidium: brown, slightly shiny, covered with shallow, rounded, dense punctuation; glabrous in some places and with scattered, recumbent, testaceous scales elsewhere; close to centre of lateral margins there are rounded white cretaceous area; two smaller similar areas are present in the centre of superior margin and close to the apex (Fig. 1); ventral half restricted to apex, laterally narrowed; a double pointed small, testaceous scale tuft at apex; apex of pygidium curves outward in lateral view.

Protibiae: brown, with five external teeth: first two long and pointed, third large, fourth, short and very close to the third, barely noticeable, fifth slightly smaller and pointed.

Meso and metatibiae: dark brown, centrally slightly enlarged, with noticeable central tooth, and some scattered, long, erect, testaceous scales; first metarsomere about twice as long as second.

Abdomen: brown, almost glabrous, with some testaceous, small, erect scales.

PARATYPE FEMALE DESCRIPTION. Length $7.3 \mathrm{~mm}$; width $4.2 \mathrm{~mm}$. Body black.

Head: black, slightly shiny, covered with round, large punctures and very scattered, erect, bristle like, testaceous scales not forming scale tufts on frons. Clypeus black, anterior margin brown and sinuate, suctorial brush shorter than in the male.

Pronotum: black, slightly shiny, glabrous, ovate but less elongated than in male, strongly crenate at sides; anterior angles obtuse; posterior angles strongly rounded; posterior margin curved towards scutellum, centrally bent downward; carinae outwardly slightly arched, sharp up to centre of disk, rounded afterward, ending at $3 / 4$ of pronotal length; there are small, black scale tuft at centre of length; central small carina not present; lateral carinae long, sharp; on lateral small carinae there are not scale tufts; four brown to black scale tufts along posterior margin, the inner two smaller than outer; remainder of surface nearly glabrous with very scattered, dark testaceous scales; small white, cretaceous areas on outer parts of posterior margin.

Scutellum: black, long, triangular, apically rounded, covered with decumbent black and brown scales.

Elytra: black, covered with decumbent, in some places inclined, black, white and testaceous scales forming a definite pattern (Fig. 2b); presence of shallow juxtascutellar depression; humeral and anteapical umbones slightly elevated, the first with a prominent black scale tuft, the second with identical scale tuft but smaller.

Propygidium: black, slightly shiny, mostly glabrous, covered with round, shallow, dense, punctuation; small, decumbent, testaceous scales present in some places; posterior margin curved inward at the middle, with two small tufts made of erect, black scales; cones long and blunt.

Pygidium: black, slightly shiny, almost glabrous, covered with round, dense, thick, punctuation; ventral half restricted to apex, laterally narrowed; apex forming a rounded bilobed projection, wider than in male; apex of pygidium, prominently curving outward in lateral view. Protibiae: brown, with five external teeth: first and third long and pointed, second and fifth small and pointed, fourth enlarged and blunt.

Meso and metatibiae: black, centrally enlarged, with prominent, four teeth at centre and some scattered, long, erect, testaceous scales; metatibia apex enlarged and slightly crenate, dorsal end long and pointed; first metarsomere apically enlarged and about twice as long as second.

Abdomen: black, almost glabrous, with some erect, testaceous setae at centre of last two visible sternites; anal sternites black, glabrous, with row of small, erect, testaceous setae on posterior margin.

REMARKS. Females can be distinguished from males for the squared pronotal shape, with lateral margins crenate, for the lack of scale tufts on carinae and small 
carinae of pronotum and for the bigger rounded projection at the apex of pygidium.

TYPE SERIES VARIABILITY. Size of males are variable as dimension, ranging from 5.6 in $6.0 \mathrm{~mm}$ in length. The two PT $q$ are about of the same dimensions: 7.9-4.5 and $8.0-4.5 \mathrm{~mm}$. Males can have the posterior margin of propygidium scale tufts made up of mixed black/testaceous or wholly black scales and the humeral humbones scales tuft testaceous instead of black.

Distribution. The type series was collected in Shaanxi, Sichuan, Gansu and Hubei.

Diagnosis. $D$. benesi can be distinguished from the other Chinese species for the four showy white cretaceous areas on pygidium. From the other species with same cretaceous areas it can be separated for having a scaly propygidium and pygidium, for the posterior corners of pronotum strongly rounded, for apex of pronotum bent apart (in lateral view). Furthermore, the shape of its parameres (Fig. 2c) is very distinctive.

Derivatio nominis. The species is named after the Czech Entomologist J. Beneš, who collected some of the types.

Dasyvalgus carbonarius Arrow, 1910 (Fig. 6f-h). STUdied MATERIAL. $4 \hat{\jmath}$ ERC, Hainan, Sanya County, Mt. Janfeng, 1/12 Jul 2004; 1 के ERC, Hainan, Wuzhishan, 1 Jun 2009. New record for China.

Distribution. The presence of D. carbonarius in Hainan extends the range of this widely distributed species (Ricchiardi 2013), known from east Nepal, Assam, Myanmar, north east Laos, and north Vietnam. REMARKS. D. carbonarius can easily be distinguished by most of the Chinese species for its black, shiny colour. The only other Chinese species completely black, D. minutus, from Xizang, is much smaller and opaque, rather than shining. The parameres, too, are very distinctive.

Dasyvalgus ichangicus Moser, 1915 (Fig. 4d,f) Studied Materials. Holotype $\widehat{\jmath}$ MNHUB, China, Ichang, 6000-8000 feet.

REMARKS. This Chinese species, described a century ago by Moser, is still only known from the HT. It lacks the four cretaceous areas on the pygidium. The propygidium is black, but with reddish cones; the pygidium is also black. Both propygidium and pygidium are covered with dense, erect, c-shaped, testaceous scales; at the propygidium posterior margin there are two very prominent testaceous scale tufts. Finally the parameres are very distinctive. The female is unknown.

Dasyvalgus inouei Sawada, 1939 (Fig. 6a-c).

= Dasyvalgus sebastiani Endrödi, 1952, syn. nov.

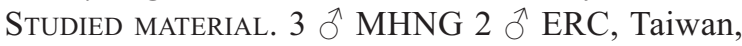
Fenchiu, 1400 m, Apr/Jun 1977, J. \& S. Klapperich legit; 4 o DAC, Taiwan, Nan Tou Co, Bei Dong Yen Shan, 1700 m, 1 Jun 1991, C.I. Li Legit; 3 ðึ GMC 1 ô ERC, Taiwan, Puli, Whuse, May/Jun 1995; 1 ภ ERC, Taiwan, Puli, Hori, May/Jul 1959; 1 ô ERC, Taiwan, Wushai, May 1961; 1 ô ERC, Taiwan, Musha, May/Jun 1960.

Moreover several types of D. sebastiani Endrödi, 1952, described from Fujian: 1 PT $\precsim$ HNHM, Fujian, Shaowu, 27 Jun 1937, J. Klapperich legit; 21 PT SNMS, Fujian, Kuatun, 20 May 1946, Tschung Sen legit; 42 PT §̊, Fujian, Kuatun, 20 May 1946, Tschung Sen legit; 1 PT $q$ ERC, Fujian, Kwangtseh, 30 Mar 1937, J. Klapperich legit; 1 PT $\widehat{\partial}$ ERC, Fujian, Kuatun, 26 Aug 1946, Tchung Sen legit; 1 PT § ERC, Kuatun, 20 May 1946, Tchung Sen legit; 1 PT $\sigma^{\wedge}$ ERC, Fujian, Kuatun, 19 Jun 1946, Tchung Sen legit.

OTHER STUDIES (some of them most likely PT, but are not labelled as such). $2 \sigma^{7}$ AMNH, Fujian, Yen-Ping, Ac 5148; 2/29 Jul 1917; 13 ๙े HNHM, Fujian, Kuatun, 20 May 1946, Tchung Sen legit; 1 đ HNHM, Fujian, Kuatun, 15 Jul 1946, Tchung Sen legit; 1 ऽิ HNHM, Fujian, Kuatun, 6 Jun 1946, Tchung Sen legit; $1 \lesssim$ HNHM, Fujian, Kuatun, 15 Aug 1946, Tchung Sen legit; 71 ○ ZFMK, Fujian, Kuatun, $27^{\circ} 40^{\prime} \mathrm{N}, 114^{\circ} 40^{\prime} \mathrm{E}$, 2300 m, 10 Aug 1938, J. Klapperich legit; 2 ô ERC, Fujian, Kuatun, 3 Aug 1946, Tchung Sen legit; 2 ภ ERC, Fujian, Kuatun, $27^{\circ} 40^{\prime}$ N, 11440’E, 2300 m, 10 Aug 1938, J. Klapperich legit; 1 है ERC, Fujian, Kuatun, 15 Aug 1946, Tchung Sen legit; 2 ¿ ERC, Fujian, Kuatun, 20 May 1946 Tchung Sen legit; Guangxi, 1 ERC, Mt. Dayaoshan, Lingxian, Jinxiu, 25 apr/5 May 2014, 700 m, HuangYuanyong \& Lidong legit.

DiAgNosis. The study of all the above mentioned material indicates that D. sebastiani Endrödi, 1952 is junior synonym of $D$. inouei Sawada, 1939.

The location of some CT of D. inouei is uncertain: while the three $\widehat{\partial}$ preserved in the Entomological Laboratory of the Tokyo Agricultural University were most likely destroyed during the Second Wold War, the actual location of the other two CT $\hat{O}$, formerly in the Hyrayama's Collection, is unknown, thus preventing their designation as NT's. 
Distribution. This species is known from Fujian, Guangxi and Taiwan.

REMARKS. The female was described by Endrödi, 1952. The author in the same work defined an ab. dolorosus based on two PT $\hat{\delta}$, with the abdomen completely black, but I have not seen such specimens. $D$. inouei can be distinguished from most of the other
Chinese Dasyvalgus as it is almost completely black and glabrous; from $D$. minutus and $D$. carbonarius, for its red propygidium and pygidium. The fifth visible sternites and the anal one too are reddish. Some specimen show a black propygidium and darker sternites.

Dasyvalgus laligantii (Fairmaire, 1888) (Fig. 4g,e).
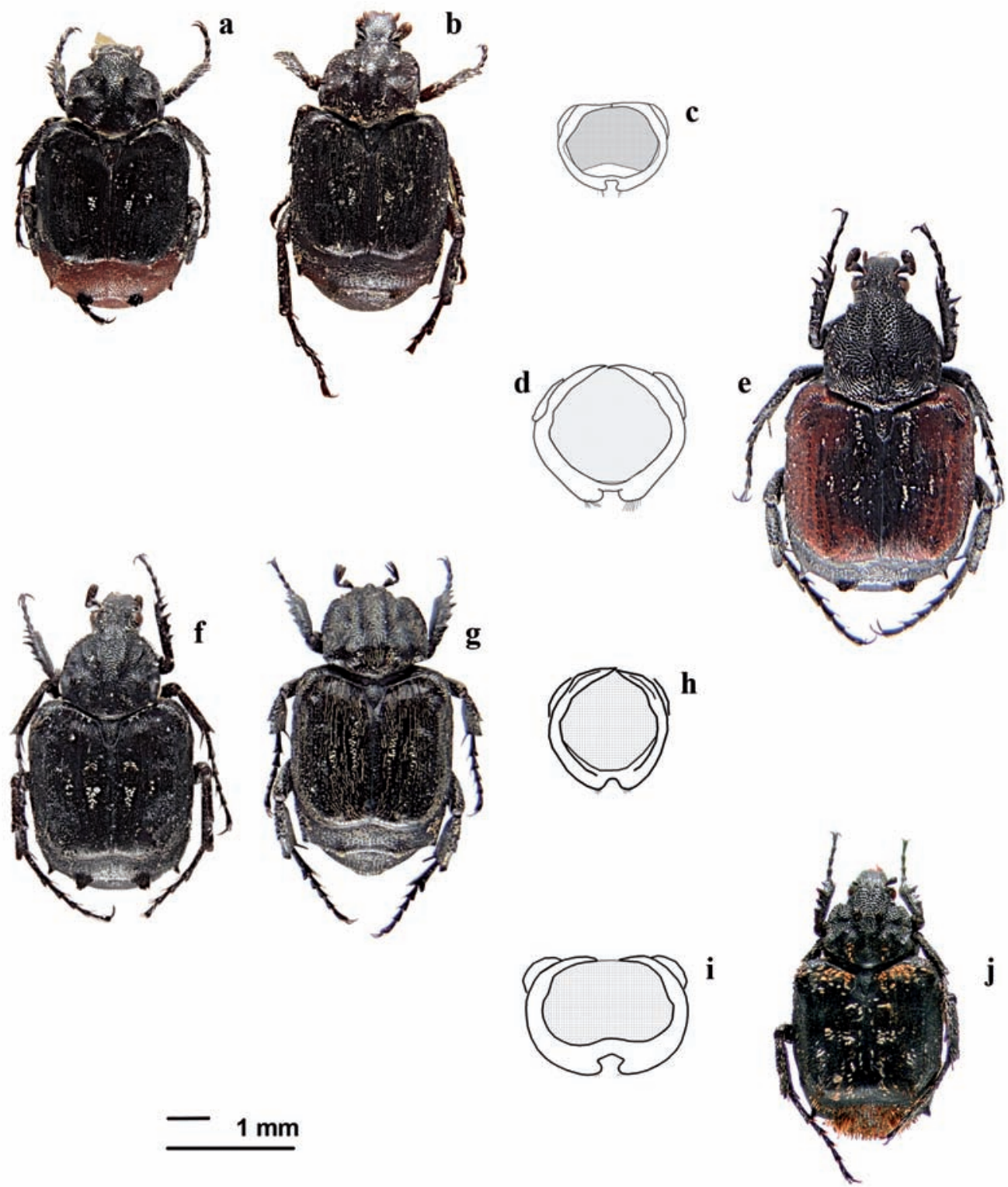

Fig. 6. Habitus and parameres of: a-c, D. inouei (a, male, b, female); d,e - D. rufipes (HT male IZAS); $\mathrm{f}-\mathrm{h}-D$. carbonarius (f, male, g, female); i,j - D. rugosus (HT male, from Ricchiardi, 2013). 
Dasyvalgus taiwanus Miyake, 1991 (nec Dasyvalgus similis Miyake, 1985).

TYPE SERIES. LT $\hat{\partial}$, here designated, MNHN (ex Coll. Léon Fairmaire), Vietnam, Tonkin.

Chinese studied material: 1 ô ANMH , China, Fujian, Yen-Ping (Yanping), 12 Sep 1917; 1 ठ̊ SDEI, China, Hong Kong (Coll. Kraatz); 1 ठ ERC, China, Fujian, Shaowu, 500 m, 10 May 1937, legit J. Klapperich; 1 ô ERC, China, Guangxi, Yangshuo, 14 Jul 1990, R. Dunda legit; 1 ô ERC, China (without detailed locality); 4 ô ERC, China, Guangxi, Mt. Dayaoshan, Lingxian, Jinxiu, 25 apr/5 May 2014, 700 m, HuangYuanyong \& Lidong legit.

Distribution. North Vietnam (locus typicus), Fujian, Hong Kong, Guangxi.

Dasyvalgus ligthbrowni Ricchiardi n. sp. (Fig. 2h,i). TYPE SERIES. HT $\widehat{0}$ NHMB, Yunnan, Dali $\left(25^{\circ} 36^{\prime} \mathrm{N}\right.$, 100¹6’E), 1600-2000 m, 5/8 Jul 1990, L. \& M.

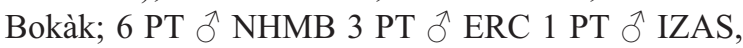
same data as the holotype; 1 PT $\delta$ SNMS, Yunnan, above Dali, 2000-2200 m, 4/17 Apr 1999, legit W. Schawaller; 2 PT ठै ERC, Yunnan, Dali, $1600-2000$ m, $1 / 7$ Jun 1994, legit B. Šiška \& T. Spevàr.

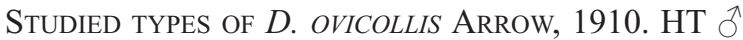
NHM, Myanmar, Birmah, Ruby Mines, Doherty; 2 PT $\widehat{ }{ }^{\lambda}$, NHM; H. ${ }^{\text {te }}$ Birmanie, Mines des Ruby, 1200-2300 m, 1890, Doherty.

HOLOTYPE DESCRIPTION. Length $5.1 \mathrm{~mm}$, width 3.2 $\mathrm{mm}$. Body light brown with head, scutellum, femurs and prosternum darkened.

Head: slightly shiny, covered with shallow, large punctures; posteriorly covered with erected testaceous scales not forming scale tufts on frons. Clypeus brown, shiny, anterior margin sinuate, covered with same punctuation as head, almost glabrous; suctorial brush longer that clypeus length.

Pronotum: ovate; covered with, in some places dense, elsewhere scattered, testaceous, recumbent scales; anterior angles acute; posterior angles obtuse, strongly rounded; lateral sides crenate; carinae sharp up to centre of disk, obtuse beyond; central small carina not present; lateral small carinae slightly noticeable; central carinae with testaceous scale tufts; lateral small carinae with small, testaceous scale tufts; posterior angles with a prominent testaceous scale tuft; carinae posterior scale tufts missing. Scutellum: long, approximately triangular, apically obtuse, covered with recumbent, testaceous scales.
Elytra: slightly shiny, mostly glabrous, with lateral margins a bit widened outward; in some places covered with black or testaceous semi-erect, small scales forming a definite pattern (Fig. 2h); humeral umbones rounded and prominent, with prominent mixed black and testaceous scale tufts; anteapical umbones noticeable, with smaller mixed testaceous and black scale tufts.

Propygidium: slightly shiny, covered with in dense some places, recumbent or inclined, sometimes coffeegrain shaped, testaceous scales; posterior margin curved inward at the middle, with two mixed testaceous/black scales; cones elevated, blunt; approximately rounded, white, cretaceous areas at centre and laterally.

Pygidium: slightly shiny, covered with dense, erect, coffee-grain shaped in some places, testaceous scales; white, rounded, cretaceous area present laterally, close to centre of lateral margins; two smaller similar areas present at centre of dorsal margin and close the apex (Fig. 1); ventral half narrowing smoothly to apex; apex rounded in lateral view and exhibiting a row of erect, testaceous scales.

Protibiae: light brown with five external teeth: first long and pointed, third long and apically rounded, second smaller and pointed, fourth large, short and blunt, fifth short and pointed.

Meso- and metatibiae light brown, centrally slightly enlarged, with noticeable central, acute tooth, and some scattered, long, erect, testaceous scales; first metarsomere about twice as long as second.

Abdomen: light brown, covered with testaceous, small, recumbent scales on the visible sternites; anal sternites brown, shiny and glabrous, but with fringe of very small, testaceous, recumbent scales at posterior margin. DisTRIBUTION. Yunnan.

REMARKS. The female is unknown.

TYPE SERIES VARIABILITY. The six types are very similar to each other. One has darker elytra and pronotum. The white cretaceous areas are more or less extended, but always four and distinguishable. The fringe of testaceous scales at apex of pygidium often looks double pointed, but without forming a true scale tuft.

Diagnosis. D. ligthbrowni can be distinguished from the other Chinese species for the four prominent white cretaceous areas present on its pygidium. It differs from the other species with same cretaceous areas, for having the body light brown instead of brown to black by having two prominent testaceous scale tufts on the 
posterior margin of propygidium. D. ligthbrown can be confused with $D$. ovicollis from Myanmar, a species with same size and colour, but it can be easily separated from this due to the shape of its parameres, which have a bigger lobe on external margin (Fig. 2i). Also in D. ligthbrowni the posterior corners of pronotum are obtuse (whereas those of $D$. ovicollis are strongly rounded) and show a testaceous scale tuft on the lateral small carinae (not present in D. ovicollis) DeRIVATIO NOMINIS. The name of the species comes from its prevailing light brown colour.

Dasyvalgus minutus Ricchiardi n. sp. (Fig. 7f,g). TYPE SERIES. HT $\widehat{\jmath}$ IZAS, China, Xizang, Xia Cha Yu, Zayu County, 28 Jul 2006; 77 PT $ぇ$ ERC, 5 PT $ぇ$ IZAS, same data as the HT.

HolotyPe DESCRIPTION. Length $4.5 \mathrm{~mm}$, width 2.8 mm. Body black.

Head: slightly shiny, covered with shallow, large, punctures. Clypeus anteriorly sinuate, suctorial brush longer than the clypeus length.

Pronotum: anteriorly narrower, sub-trapezoidal, crenate at sinuate sides; hind angles obtuse; carinae outwardly arched, sharp up to the centre of disk, blunt beyond this, ending around $3 / 4$ of the pronotum length; central small carina not present; small lateral carinae obsolete; scale tufts on central small carinae small and black; carinae posterior scale tufts as above; posterior angle scale tufts small and black. surface of disc rugose, glabrous

Scutellum: short, triangular, apically obtuse, glabrous. Elytra: slightly shiny, mostly glabrous; humeral and anteapical umbones with a small scale tuft made of few, erect, black scales.

Propygidium: opaque, glabrous, covered with round, thick punctuation; two prominent black scale tufts at posterior margin.

Pygidium: opaque, covered with same punctures as propygidium, narrowing towards apex; scattered, erect, bristle like, black scales close to the lateral margins and apex.

Protibiae: with five external teeth: first three long and pointed, fourth and fifth smaller and pointed. Meso and metatibia centrally enlarged, with noticeable central tooth, and some very scattered, long, erect, bristle like, black scales; first metarsomere about twice as long as second.

Abdomen: glabrous, covered with round, shallow, large punctuation.
Distribution. The type series was collected in Xizang), in the Zaiü County, a valley that ends in Arunachal Pradesh.

REMARKS. The female is unknown.

TYPE SERIES VARIABILITY. Within the paratypes there are no noticeable variations.

Diagnosis. D. minutus can be easily recognized for its reduced dimension (Fig. 7f), being the smallest of the Chinese Dasyvalgus, and because it is completely black. The only other completely black Chinese species, $D$. carbonarius, shining body, while $D$. $\mathrm{min}$ utus is opaque, and it is much bigger. The parameres are also distinctive (Fig. 7g).

DERIVATIO NOMINIS. The name of this species derived from its small size.

Dasyvalgus montivagus Moser, 1915 (Fig. 2d,e)

TYPE SERIES (here designated). Lectotype $\delta$ MNHUB, Vietnam, Tonkin, Montes Mauson, 2-3000 feet, MayJun, H. Fruhstorfer legit; 8 PLT $\widehat{\jmath}$ MNHUB, same data as LT.

Other EXAmined MATERIAL: 1 ô ERC, Guangxi, Mt. Dayaoshan, Linxiang, Jinxiu, 700 m, 25 Apr/5 May 2014, HuangYuanyong \& Lidong legit.

Distribution. This species, previously know from North Vietnam only (Moser 1915; Paulian 1961) extend its range to Guangxi too.

REMARKS. The females is unknown.

Diagnosis. From the other Chinese species D. montivagus can be separated for the four prominent cretaceous areas on pygidium. From the other species with same cretaceous areas for having the pygidium mostly glabrous. The parameres too are distinctive.

TYPE SERIES VARIABILITY. The specimen from Guangxi differs from the type series only for having cpt's obsolete. Being the parameres shape, both in superior and lateral views, identical if the Guangxi specimen at end will prove to belong to a subspecies or not will depend on the exam of more material.

Dasyvalgus motuoensis Ricchiardi n. sp. (Fig. 7a,b). TYPE SERIES. HT $\widehat{\jmath}$ IZAS, China, Xizang, Motuo District, Hanmi, Aug 2013. 1 PT $\precsim$ ERC, same data as the holotype.

HOLOTYPE DESCRIPTION. Length $5.9 \mathrm{~mm}$, width 3.3 mm. Body black.

Head: slightly shiny, covered with small punctures and dense, inclined yellowish scales forming two small scale tufts on frons. Clypeus anteriorly slightly sinu- 
ate, covered with same punctures and very scattered, inclined yellowish scales; suctorial brush longer that the clypeus length.

Pronotum: anteriorly narrower, semi-trapezoidal, noticeably crenate at sinuate sides; anterior angles acute and sharp, posterior one obtuse; medially convexly arcuate; carinae obsolete; central small carina not present, lateral small carinae obsolete; covered with very dense, recumbent, long, C-shaped yellowish scales.

Scutellum: triangular, longish, apically obtuse, covered with very dense, recumbent, yellowish scales.

Elytra: covered with very dense, recumbent yellowish scales except for areas around umbones, centre of lateral declivity and centre of disc where the scales are black; scale tufts on humeral umbones yellowish and prominent.

Propygidium: covered with very dense, recumbent, coffee-grain like, yellowish scales forming two prominent scale tufts at posterior margin.

Pygidium: narrowing towards apex, covered with very dense, recumbent (in some places semi-erect) yellowish scales forming fringe at apex.

Protibiae: with five external teeth: first and third long and pointed, second, fourth and fifth short and pointed. Meso and metatibia centrally enlarged, with noticeable central tooth, and long, inclined, bristle like, yellowish scales. First metarsomere about twice as long as second. Abdomen: covered with recumbent, very dense, yellowish scales; anal sternites mostly glabrous

Distribution. The type series was collected in south Xizang, in the Motuo County.

REMARKS. The female is unknown.

TYPE SERIES VARIABILITY. The PT is a bit shorten than the HT (5.4 mm, width $3.1 \mathrm{~mm})$, the scale tufts on its pronotum are darker, most of the scales on lateral declivity and posterior margin of elytron are blackish.

Diagnosis. D. motuoensis can be distinguished from the other Chinese Dasyvalgus for the propygidium and pygidium, which are covered with dense and yellowish coffee-grain shaped decumbent scales; for the prominent, testaceous, scale tufts of the posterior margin of propygidium, etc. The parameres too are distinctive (Fig. 7b). Within the Chinese Dasyvalgus, D. motuoensis can only be potentially confused with $D$. penicillatus from it which can be distinguished for the carinae (present, rounded, arched outwardly, ending at centre of disk in D. motuoensis; obsolete in D. penicillatus). The parameres of $D$. penicillatus (Fig. 7c) are similar but distinct from those of D. motuoensis (Fig. 7b) .
Dasyvalgus paratomentatus Ricchiardi n. sp. (Fig. $2 \mathrm{f}, \mathrm{g})$.

TYPE SERIES. HT ঐ IZAS, China, Yunnan, $100 \mathrm{Km} \mathrm{W}$ of Kummig, Diaolin Nat. Res., 22 May/2 Jun-1993,

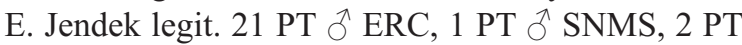
IZAS, same data as the HT.

HolOtYPE DESCRIPTION. Length $6.3 \mathrm{~mm}$, width 3.7 mm. Body brown.

Head: black, slightly shiny, covered with shallow, large punctures and with scattered, inclined, testaceous scales forming three scale tufts on frons. Clypeus pale brown, almost glabrous, anteriorly sinuate, covered with same punctuation; suctorial brush longer that the clypeus length.

Pronotum: black or brown in some places, ovate, medially convexly arcuate; anterior angle acute, posterior angle obtuse; lateral sides crenate; carinae sharp up to centre of disk, rounded beyond this; central small carina not present; lateral small carina obsolete; covered with dense, testaceous, recumbent scales in some places; lateral small carinae covered with testaceous scale tufts; mixed testaceous/black scaled tufts at centre of carinae; scale tuft on posterior angle prominent and testaceous; carina posterior tuft small, made with mixed testaceous/black scales.

Scutellum: long, brown, approximately triangular, apically obtuse, covered with recumbent, testaceous scales. Elytra: slightly shiny, mostly glabrous, brown or black in some places, with lateral margins slightly widened; covered with black or testaceous, recumbent small scales forming a definite pattern (Fig. 2f) in some places; humeral umbones rounded and prominent, with showy black and testaceous scale tufts; anteapical umbones noticeable, with smaller black scale tufts.

Propygidium: brown, slightly shiny, covered with dense, recumbent, coffee-grain shaped, testaceous scales in some places; posterior margin curved inward at the middle, with two tufts made of erect, black scales; cones sharp; rounded, white, cretaceous area at centre and laterally.

Pygidium: brown, slightly shiny, covered with shallow, rounded, dense punctuation; covered with dense, recumbent, coffee-grain shaped, testaceous scales in some places; two small whitish cretaceous areas present at centre of dorsal margin and close to apex (Fig. 1); ventral half smoothly narrowing toward apex; apex rounded in lateral view and without scale tuft.

Protibiae: dark brown to black, with five external 
teeth: first and third long and pointed, second smaller and pointed, fourth large, short and blunt, fifth short and blunt.

Meso- and metatibiae: dark brown, centrally slightly enlarged, with noticeable central tooth, and some scattered, long, erect, testaceous scales; first metarsomere about twice as long as second.

Abdomen: dark brown, covered with testaceous,
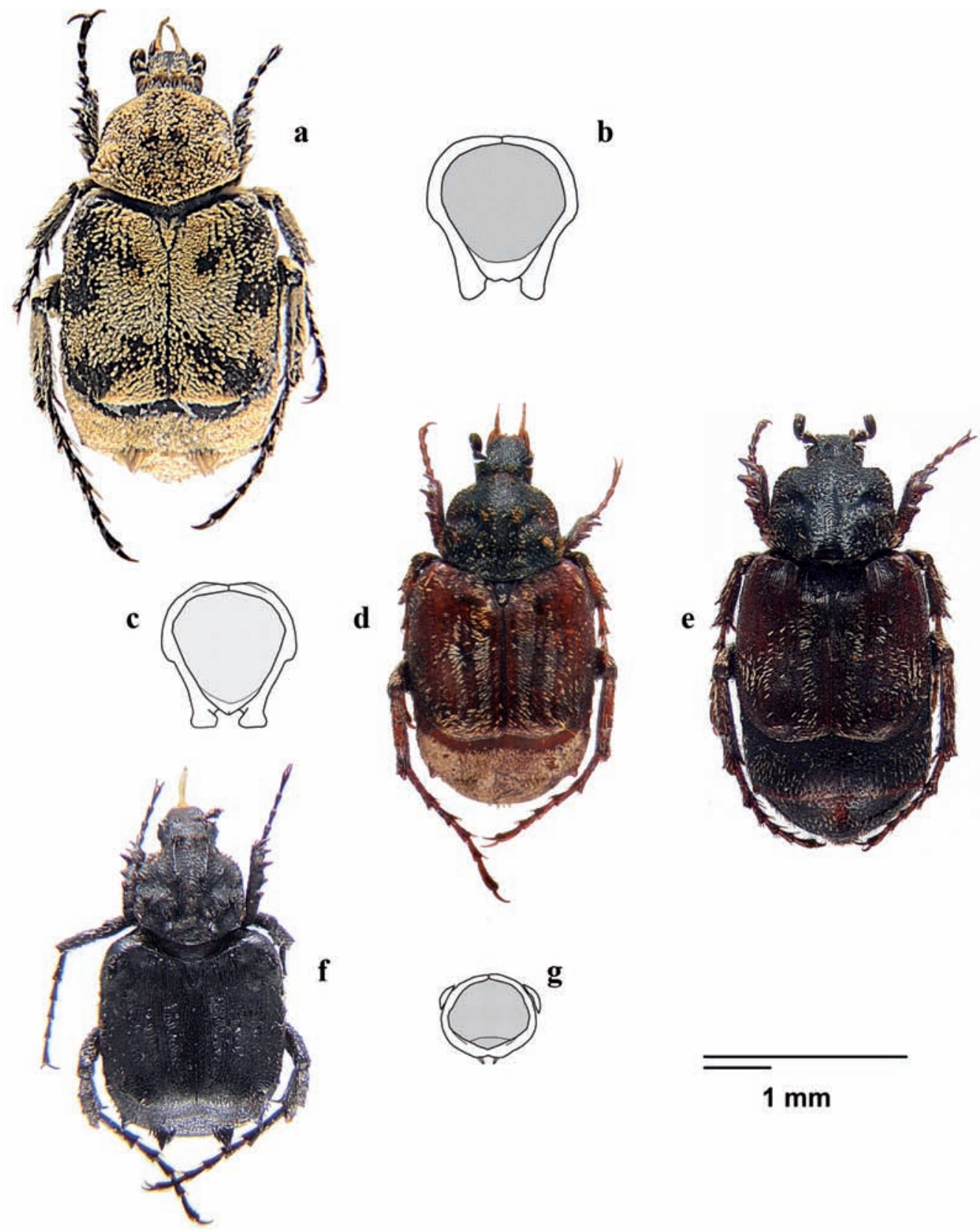

Fig. 7. Habitus and parameres of: a,b - D. motuoensis (HT male IZAS); c-e - D. penicillatus (d, male, e female, from Ricchiardi, 2012); f,g - D. minutus (HT male IZAS). 
small, recumbent scales on visible sternites; anal sternites brown, shiny and glabrous.

DisTRIBUTION. The type series was collected in Yunnan. REMARKS. The female is unknown. One paratype was collected on flowers of Castanea sp.

TYPE SERIES VARIABILITY. All the PT's are very similar to the HT, but their length varies from 5.9 to $6.3 \mathrm{~mm}$. In some PT the lateral lobe at the centre of the outer margin of the parameres is slightly wider than average. Diagnosis. D. paratomentatus can be separated from the other Chinese species for the four prominent white cretaceous areas on pygidium. Although similar to $D$. tomentatus, $D$. paratomentatus can be distinguished with difficulty for its lighter clypeal colour and for scale tuft on anteapical umbones made of mixed black and testaceous scales (in D. tomentatus black that are purely black). In any case, the only conclusive way of distinguishing the two species is by comparing the shape of their parameres (Fig. 2g,1).

Dasyvalgus penicillatus (Blanchard, 1850) (Fig. 7c-e). TYPE SERIES. LT $\widehat{\jmath}$ MNHN, Inde Sept. (without further data).

Other studied material. 1 ô ERC, China, Tibet, Motuo County, Hanmi, Aug 2013. New record for China.

REMARKS. This is first record for this species in China. The Motuo County is a Tibetan valley ending in Arunachal Pradesh, which exhibits a Dasyvalgus fauna similar in some extent to that of the Pre-Himalayan Sub region one (Ricchiardi, 1998, 2012). Due to lack of recent records, potential relationships with the Myanmar's Dasyvalgus cannot be defined.

The D. penicillatus specimen from Xizang is brown, while the specimens from Nepal are more often blackish. The only Chinese species similar to D. penicillatus is D. motuoensis, which is longer (Fig. 7a). The parameres are distinctive (Fig. 7b,c). The female of $D$. penicillatus can be distinguished from its male for wider protibia, more squared pronotum, longer propygidium, lobed apex pygidium and posterior margin of pronotum centrally two pointed toward scutellum.

Dasyvalgus rufipes Ricchiardi n. sp. (Fig. 6d,e). TyPe SERIES. HT $\lesssim$ IZAS, China, Hainan, Sanya County, Mt. Janfeng, 1/12 Jul 2004. 9 PT $\widehat{\jmath}$ ERC, same data as the holotype; 1 PT $\delta$ ERC, Guanxi, Dayaoshan, Pingzhao, Jinxiu, 15/25 May 2014, Zhaojinsheng legit;1 PT ô ZFMK, Laos, Ban Saleui, Phou
Pan Mt., $20^{\circ} 12^{\prime} \mathrm{N}, 104^{\circ} 01^{\prime} \mathrm{E}, 1300-1900$ m, 1/31 May 2011, legit C. Holzschuh.

HolOTYPE DESCRIPTION. Length $6.5 \mathrm{~mm}$, width 4.0 mm. Body black.

Head: slightly shiny, glabrous, covered with shallow, large, confluent punctures; frons with a rounded prominence at centre. Clypeus anteriorly sinuate, covered with same puncture as above; suctorial brush longer that the clypeus length.

Pronotum: black, trapezoidal, glabrous, medially convexly arcuate; anterior angles acute; posterior angles with apex pointed; lateral sides crenate, hollow internally; covered with very large, shallow punctures, rugose at posterior angles and posterior part of lateral margins; carinae obtuse, semi-parallel, ending at centre of disk; central and lateral small carinae not present; only four small, black scale tufts present along posterior margin.

Scutellum: long, black, brown at centre, approximately triangular, apically obtuse, with very scattered recumbent, testaceous scales.

Elytra: slightly shiny, mostly glabrous, laterally red, centrally blackish, with lateral margins slightly widened outward; second interstriae with small erect, dense scales, black at centre, testaceous elsewhere; fourth interstriae with some small, erect, scattered, testaceous scales; humeral umbones rounded and prominent, with black scale tufts; anteapical umbones slightly noticeable, without scale tufts.

Propygidium: black, rugose, opaque, glabrous; posterior margin curved inward at the middle, with two small black scale tufts; cones sharp.

Pygidium: black, opaque, glabrous, rugose, ventral half restricted to apex, which exhibit a round prominence; apex bent apart in lateral view and exhibiting fringe of small, testaceous scales.

Protibiae: black, with five external teeth: first to third long and pointed, fourth and fifth small and pointed.

Meso and metatibia: black, glabrous, slightly enlarged, with noticeable central tooth. First metarsomere about twice as long as second, apically externally pointed.

Abdomen: black, glabrous, covered with large, rounded, shallow punctuation; anal sternites brown, shiny and glabrous.

Distribution. The species is known from Hainan Island and Laos.

DERIVATIO NOMINIS. The species is named after its typically red elytrae.

REMARKS. The female is unknown. 
TYPE SERIES VARIABILITY. PT's are very similar to HT. Diagnosis. D. rufipes can be easily recognized by being mainly glabrous, with body black and elytrae mainly red; the parameres are distinctive (Fig. 6d).

Dasyvalgus rugosus Ricchiardi, 2013 (Fig. 6i,j, Ricchiardi, 2013).

TYPE SERIES. HT § NMER, China, Yunnan (without further data).

REMARKs. The female is unknown. This Chinese species, known from the HT only, can be easily distinguished for the scattered, orange, erect scales on propygidium and pygidium (Fig. $6 \mathrm{j}$ ). The parameres are also distinctive (Fig. 6i).

Dasyvalgus sommershofi Endrödi, 1952 (Fig. 4h,j). STUdied TYPes. 1 PT $\delta$ NHM 1 PT $\delta$ ERC, Fujian, Kuatun, 20 May 1946, Tchunh Sen legit; 1 PT $\delta$ ERC, same data but 6 Jun 1946; 1 PT $ठ \widehat{E R C}$, same data but 6 Sep 1946.

Other studied material. 6 तFMK, 1 ERC, Fujian,

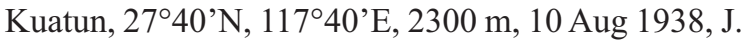
Klapperich legit; 1 ô 1 \& ERC, Fujian, Kuatun, 22 Jul 1946, Tchunh Sen legit (These two specimens should belongs to the Endrödi type series, but they were not labelled as such); 1 O ERC, Fujian, Wuyi Gong, 1/3 Jul 1991, M. Nicodym legit.

FEMALE FIRST DESCRIPTION. Length $5.8 \mathrm{~mm}$; width 3.4 mm. Body brown.

Head: black, slightly shiny, covered with scattered, erect, testaceous scales not forming scales tufts. Clypeus brown, sinuate at anterior margin; with scattered, erect, bristle like, testaceous scales; suctorial brush much shorter than in the male.

Pronotum: brown, enlarged ovate, shiny, covered with large, shallow, rounded punctuations, many of which have a white, cretaceous marking inside; strongly crenate at sides; anterior and posterior angles obtuse; posterior margin curved towards scutellum, centrally slightly bent downwards; carinae outwardly slightly arched, rounded up to centre of disk, obsolete beyond this, ending at $3 / 4$ of pronotum length; central small carina not present; lateral carinae long, sharp; only four scale tufts are present on the postero-lateral umbones, consisting of a few long, testaceous, erect scales; remainder of surface mostly glabrous, but with very scattered, bristle like, testaceous scales; close to the posterior angles, into the lateral depressions, the posterior part of a central line long as all pronotum and close to the anterior angles, there is a white, testaceous clothing.

Scutellum: brown, glabrous, rugose, long, triangular, apically obtuse.

Elytra: brown, shiny, mostly glabrous; with a shallow juxtascutellar depression; humeral and anteapical umbones slightly elevated, with hardly noticeable tufts made of erect, bristle like, testaceous scales; rows of white, cretaceous spots present in all the striae and at centre of interstriae.

Propygidium: brown, slightly shiny, glabrous, covered with big, shallow, round and dense punctuation often bearing inside white, cretaceous markings; posterior margin curved inward at the middle, with two small tufts made of erect, bristle like, testaceous scales; cones elevated and blunt.

Pygidium: brown, slightly shiny, almost glabrous, covered with large punctuation and bristle like scales as in propygidium; ventral half narrowing sharply toward apex, which exhibits a pointed projection; apex of pygidium is very arched in lateral view.

Protibiae: brown, enlarged, with five external teeth: first long and pointed, second very sort, enlarged and blunt, third long and blunt, fourth enlarged and very blunt, fifth, short, enlarged and blunt.

Meso and metatibiae dark brown, centrally enlarged, with a noticeable sharp tooth, and some scattered, long, erect, testaceous scales; metatibial apex enlarged, pointed centrally and at sides; first metarsomere slightly less than twice the length of second; first metatarsomere apically slightly enlarged and spiny.

Abdomen: brown, almost glabrous, covered with scattered, large, shallow, rounded punctuation containing white cretaceous spots in the last two visible sternites. Anal sternites brown, glabrous, with a row of small, erect, bristle like, testaceous scales at posterior margin. Distribution. The species is known from Fujian.

REMARKS. The specimens could be confused with $D$. laligantii, but they are much less scaly. Moreover, the propygidium scale tufts on their propygidium are testaceous whereas in D. laligantii they are blackish. The parameres of $D$. sommershofi (Fig. $4 \mathrm{j}$ ) are distinctive. The female can be distinguished from the male for the wider protibia, the longer propygidium, the shape of the pygidium, etc.

Dasyvalgus tomentatus Ricchiardi sp.n. (Fig. 2k,1). TYPE SERIES. HT đ̊ IZAS, Yunnan, Lijang, 8/24-Jun-

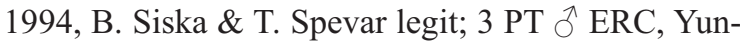


nan, Lijiang, Same data as the HT; 8 PT $\delta$ ZMUC, 1 PT ô ERC, Yunnan, 9-Sep-1919, Simeon Tèn legit; 6 PT $\lesssim$ ERC, Yunnan, Lijiang, 31-May-1997; 1 PT $\lesssim$ IZAS, Yunnan, Wuding County, Bailu $\left(25^{\circ} 32^{\prime} 16^{\prime \prime} \mathrm{N}\right.$, $102^{\circ} 24^{\prime} 38^{\prime \prime}$ ), 2600 m, 4 Jun 1980, Li Shengyuan legit; 1 PT ते IZAS, Yunnan, Weixi Pantiage (27²0'13”N, 99¹3'41'”E), 3500 m, 24 Jul 1987, Zhang Xuezhong legit; 1 PT $\widehat{\partial}$ IZAS, Sichuan, Yajiang, Bajiaolouxiang $\left(30^{\circ} 04^{\prime} 44^{\prime \prime} \mathrm{N}, 101^{\circ} 08^{\prime} 36^{\prime \prime} \mathrm{E}\right), 29$ May 2009, Wang Zhiliang legit; 1 PT $\delta$ IZAS, Sichuan, Mianning (28 $\left.33^{\prime} 23^{\prime} \mathrm{N}, 102^{\circ} 11^{\prime} 03^{\prime \prime} \mathrm{E}\right), 5$ VIII-1958.

HOLOTYPE DESCRIPTION. Length $6.5 \mathrm{~mm}$, width 3.6 mm. Body black.

Head: black, slightly shiny, covered with shallow, large punctures and with scattered, decumbent, testaceous scales forming three scale tufts on frons. Clypeus brown, almost glabrous, anteriorly sinuate, covered with same punctuation; suctorial brush longer than the clypeus length.

Pronotum: black, ovate, medially convexly arcuate; anterior and posterior angles obtuse; lateral sides crenate; carinae sharp up to centre of disk, rounded beyond this; central small carina not present; lateral small carinae obsolete; covered with dense, testaceous, recumbent scales; central carina scale tuft black; lateral small carina with small testaceous scale tuft; posterior angle scale tuft testaceous; carina posterior tuft prominent and testaceous.

Scutellum: long, brown, approximately triangular, apically obtuse, covered with recumbent, testaceous scales. Elytra: shiny, brown or black in some places, with lateral margins slightly widened outward; covered with black or testaceous inclined small scales forming a definite pattern in some places (Fig. 2k); humeral umbones rounded and prominent, with showy black scale tufts; anteapical umbones noticeable, with smaller black scale tufts.

Propygidium: black or brown in some places, shiny, covered with dense, recumbent, coffee-grain shaped, testaceous scales in some places; posterior margin curved inward at the middle, with two tufts consisting of erect, black and testaceous scales; cones sharp; rounded, white, cretaceous areas present at centre and laterally.

Pygidium: black or brown in some places, shiny, covered with shallow, rounded, dense punctuation; covered with dense, recumbent, coffee-grain shaped, testaceous scales in some places; rounded, white, cre- taceous area laterally, close to centre of lateral margins; two smaller similar areas at centre of dorsal margin and close to apex (Fig. 1); ventral half narrowing smoothly toward apex; apex rounded in lateral view and without scale tuft.

Protibiae: dark brown, with five external teeth: first and third long and pointed, second smaller and pointed, fourth large, short and blunt, fifth short and blunt.

Meso- and metatibiae: dark brown, centrally slightly enlarged, with noticeable central tooth, and some scattered, long, erect, testaceous scales; first metarsomere about twice as long as second.

Abdomen: black, covered with testaceous, small, recumbent scales on visible sternites; anal sternites brown, shiny and glabrous.

REMARKS. The female is unknown.

TYPE SERIES VARIABILITY. The PT's are quite close to the HT. Their length vary from 5.5 to $6.5 \mathrm{~mm}$.

Distribution. The species is known from Yunnan and Sichuan.

Diagnosis. D. tomentatus can be separated from the other Chinese species for the four prominent white cretaceous areas on the pygidium. Compared to the other species $D$ tomentatus is particularly close to $D$. Paratomentatus and can be distinguished with difficulty mainly by exhibiting a darker clypeal colour and, for the scale tufts on the anteapical umbones of its elytra consisting of black scales (versus mixed testaceous/black in D. paratomentatus). However, the only conclusive way to distinguish the two species is through the shape of their parameres (Fig. 21).

Dasyvalgus varius Ricchiardi n. sp. (Fig. $2 \mathrm{~m}, \mathrm{n}$ ).

TYPE SERIES. HT $\delta$ IZAS, Sichuan, Shimian, Liziping Nature Reserve (2902'4'N, 102 $22^{\circ}$ '45”E), 2012 m, 23 Jun 2012, Yang Ganyan legit; 1 PT $\widehat{\jmath}$ ERC, Sichuan, Mt. Emeishan, 27-May-1990, Hajime Nara legit.

HOLOTYPE DESCRIPTION. Length $6.2 \mathrm{~mm}$, width $3.4 \mathrm{~mm}$. Head: black, slightly shiny, covered with shallow, large punctures and with scattered, inclined, testaceous scales forming two scale tufts on the frons. Clypeus brown, anteriorly sinuate, covered with same punctuation, almost glabrous; suctorial brush longer that the clypeus length.

Pronotum: black, ovate, medially convexly arcuate; anterior and posterior angles obtuse; lateral sides crenate; carinae sharp up to the centre of disk where they ends; central small carina not present; lateral small carinae short, posteriorly facing outwards; almost 
glabrous, with scattered, testaceous, recumbent scales in some places; scale tufts on central carina black; small lateral carinae without scale tufts; scale tufts on posterior angles black and testaceous; carina posterior scale tufts not present.

Scutellum: long, dark brown with sides black, triangular, apically obtuse, covered with recumbent, testaceous scales.

Elytra: brown, shiny, with lateral margins slightly widened; covered with black, yellow or testaceous, inclined small scales forming a definite pattern in some places (Fig. 2m); humeral umbones rounded and prominent, with black and testaceous scale tufts; anteapical umbones slightly noticeable, with smaller black and testaceous scale tufts.

Propygidium: black or brown in some places, shiny, covered with very scattered, erect, bristle like, testaceous scales; posterior margin curved inward at the middle, with two tufts made of erect, black scales; cones sharp; rounded, white cretaceous areas present at centre and laterally.

Pygidium: glabrous, shiny, covered with shallow, rounded, dense punctuation and with erect, bristle like, testaceous scales; a rounded, white, cretaceous area present laterally, close to centre of lateral margins; two smaller similar areas present at centre of dorsal margin and close (Fig. 1); ventral half narrowing towards apex; apex obtuse in lateral view and exhibit a small, testaceous, double pointed scale tuft.

Protibiae: dark brown, with five external teeth: first and third long and pointed, second smaller and pointed, fourth small, short and blunt, fifth short and pointed.

Meso- and metatibiae dark brown, centrally slightly enlarged, with a central tooth, and some scattered, long, erect, testaceous scales; first metarsomere about twice as long as second.

Abdomen: brown, covered at centre with testaceous, erect scales on the visible sternites; anal sternites shiny and almost glabrous.

DISTRIBUTION. This species is known from a two specimens coming from Sichuan.

TYPE SERIES VARIABILITY. The PT $\precsim$ ERC has body brown instead of black; its umbones scales tufts are only made with black scales, instead of mixed testaceous/black as the HT.

REMARKS. The female is unknown.

Diagnosis. D. varius can be separated from the other Chinese species for the four prominent white cretaceous areas on the pygidium. Within the species that show four whitish cretaceous areas on pygidium, this species can be distinguished for its mostly glabrous propygidium and pygidium and for the propygidium posterior margin scale tufts formed of black scales. The shape of its parameres is also very distinctive (Fig. 2n).

\section{Species eXCluded from China Fauna}

Dasyvalgus sellatus (Kraatz, 1883).

TYPE SERIES (here designated). LT $\widehat{\partial}$ SDEI (Coll. Kraatz), Malacca; 5 PT $\delta$ SDEI, 1 PT $\lesssim$ ZMHA, Malacca.

Remarks. In his Catalogue of the Chinese Cetoniidae, Krajcik (2011), quoting Kraatz (1883, pages 375 - 376), wrote that $D$. sellatus is present in Hong Kong. However the only specimen determined by Kraatz as $D$. sellatus (which do not appears to be part of the type series) labelled "Hong Kong" is actually a D. laligantii.

D. sellatus is known so far from the Malaysian Peninsula only, but could inhabits other Sundaland areas. Its parameres are very different from those of D. laligantii (Fig. 4k). The female is unknown.

Key of MALES (including D. ovicollis Arrow, 1910 from Myanmar; see Taxonomy section of this work).

1. Pygidium with four prominent white cretaceous areas (Fig. 1) …....................................................

2. Pygidium without such cretaceous areas or with barely noticeable cretaceous markings .............. 8 Propygidium with two prominent testaceous scales tufts at posterior margin; body mainly light brown, sometimes brown in some places..........................3 Propygidium with two small black or mixed black/testaceous scales tufts at posterior margin; body brown to black.

3. Posterior angles of pronotum obtuse; pronotum lateral small carinae scale tufts present and testaceous .ligthbrowni $\mathrm{n} . \mathrm{sp}$.

Posterior angles of pronotum obtuse and strongly rounded; pronotum lateral small carinae scales tufts not present. ovicollis (Myanmar)

4. Pygidium mostly glabrous ...................................5 Pygidium more or less covered with scales ........6

5. Propygidium mostly glabrous ......................varius Propygidium covered with recumbent, testaceous scales. montivagus

6. Pronotal carinae present but obtuse and ending at centre of disk; posterior angles of pronotum strongly rounded; apical fifth of pygidium elevated 
(lateral view)

benesi

Pronotal carinae present and sharp; posterior angles of pronotum obtuse, but not strongly rounded; apex of pronotum rounded in lateral view

7. Propygidium with two small black scale tufts at posterior margin .paratomentatus

Propygidium with two small black/testaceous scale tufts at posterior margin. tomentatus

8. Propygidium, pygidium, pronotum and elytra mostly glabrous (but with some scale tufts)........9 Propygidium, pygidium, pronotum and elytra mostly scaly.

9. Head, pronotum, elytron, propygidium and pygidium black 10

Head black, elytron or pygidium/propygidium red .11

10. Body small (shorter than $4.5 \mathrm{~mm}$ ); pronotal carinae present but obtuse, arched outwardly, ending at centre of disk; apex of pygidium regularly rounded minutus

Body larger; pronotal carinae present but obtuse, arched outwardly, ending well after centre of disk; pygidium narrowing toward apex......carbonarius

11. Elytra red; propygidium and pygidium black ....... rufipes

Elytra black; propygidium and pygidium red ....... ..inouei

12. Pronotum black, very rugose, with prominent, sharp outwardly arched central carina, ending a bit before centre of disk; propygidium and pygidium black, covered with scattered, erect, bristle like orange scales .rugosus Pronotum not very rugose; propygidium and pygidium covered with different scales 13

13. Propygidium and pygidium covered with dense, recumbent, coffee-grain like, testaceous scales ...

Propygidium and pygidium with different scales or glabrous 15

14. Propygidium and pygidium ground colour black; pronotal carinae present, rounded, arched outwardly, ending at centre of disk ..........motuoensis Propygidium and pygidium ground colour brown; pronotal carinae obsolete. penicillatus

15. Propygidium and pygidium almost glabrous; pygidium narrowed to the apex, where there is a rounded projection .becvariensis

Propygidium and pygidium scaly .... .16

16. Propygidium and pygidium black (but cones reddish), covered with dense, erect, C-shaped, testaceous scales; posterior margin of propygidium with two very prominent testaceous scale tufts; apex of pygidium with double pointed, prominent, testaceous scale tuft ............................ichangicus Propygidium and pygidium brown, covered with different scales

17. Posterior corners of pronotum with apex pointed; carinae posterior scale tufts testaceous; propygidium posterior margin scale tufts testaceous; propygidium and pygidium without white cretaceous markings sommershofi Posterior pronotal corners obtuse; carinae posterior scale tufts black; propygidium posterior margin scale tufts black; propygidium (around cones) and pygidium (close to the superior corners) with some barely noticeable white cretaceous markings. laligantii

\section{ACKNOWLEDGMENTS}

We thank Lynette Clennel, Ming Bai, Paul Lago, Renzo Perissinotto and Guido Sabatinelli for their effort in reading the various drafts of this work suggesting many corrections aimed to improve the English version and to increase the understanding of descriptions. Sha Li research was supported by the National Basic Research Program of China (973 Program, 2011CB302102). 


\section{REFERENCES}

Arrow G., 1910 - The fauna of British India including Ceylon and Burma. Coleoptera: Lamellicornia: Cetoniinae and Dynastinae. London.

Jameson M.L., Swoboda K.A., 2005 - Synopsis of Scarab Beetle Tribe Valgini (Coleoptera:Scarabaeidae: Cetoniinae) in the New World. Annals of the Entomological Society of America, Columbus, Washington, 98 (5): 658-672.

KrAAtz G., 1883 - Ueber die Gattung Valgus und eine Anzhal neuer Arten derselben. Deutsche Entomologisches Zeitschrift, Berlin. XXVII, Heft II: 373-379.

KrajCIK M., 2011 - Illustrated Catalogue of Cetoniinae, Trichiinae and Valginae of China (Coleoptera : Cetoniidae). Animma. X, Supplement 1/2011, Plzen.

Moser J., 1915 - Neue Melolonthiden un Cetoniden (Col.). Deutsche Entomologische Zeitschrift, Berlin: 579-605.

Ling C., Yanling S., Shufang X., 2008 - The boundary of palaeartic and oriental realms in western China. Science Direct, Progress in Natural Science, 18: 833-841.

Palestrini C., Simonis A., Zunino M., 1985 - Modelli di distribuzione dell'entomofauna della Zona di Transizione Cinese, analisi di esempi e ipotesi sulle sue origini. Biogeographia, Bologna, 9: 195-209.

Paulian R., 1961 - Coléoptères Scarabéides de l'Indochine (Rutélines et Cétonines). Annales de la Société Entomologique de France, Paris, 130: 1-47 (225-271).

Ricchiardi E., 1994 - Revision of the Valginae from Himalaya (Coleoptera, Scarabaeoidea, Cetoniidae). Fragmenta Entomologica, Roma, 26(1): 165-177, 16 figg.

Ricchiardi E., 1998 - Notes on the genus Dasyvalgus Kolbe, with description of two new species (Coleoptera, Cetoniidae, Valginae). Mitteilungen der Museum Naturkunde Berlin. Zoologische Reihe 74(2): 243-247, 4 figs.

RicCHIARDi E., 2012 - Notes on the Himalayan Valgina with description of a new genus. Biodiversität und Naturausstattung im Himalaya IV. Herausgegeben von Matthias Hartmann \& Jörg Weipert. Verein der Freunde \& Förderer des Naturkundemuseums Erfurt, 5: 323-328.

Ricchiardi E., 2013 - Description of eight new Dasyvalgus and notes on other Valgina (Coleoptera: Cetoniinae). Bollettino della Società Entomologica Italiana, Genova, 145(3): 129-139. 